\title{
Jatio Sangsad Bhaban Complex: The Emergence of Neocolonial Capitalist Planning in Dhaka as a Sequel
}

\author{
Bayezid Ismail Choudhury, Dr. Peter Armstrong, Dr. Paul Jones \\ Faculty of Architecture and Planning, University of Sydney
}

\begin{abstract}
Jatio Sangsad Bhaban (JSB), the National Assembly Complex in Bangladesh (Former East Pakistan) envisioned in 1962, followed by the 1959 Minoprio, Master plan initiated the new phase of modern space creation in the landscape of Dhaka. Dhaka, the capital of Bangladesh, grew towards north from the bank of Buriganga river went through a series of transformation over $\mathbf{4 0 0}$ years. The locally controlled growth of old Dhaka during the $17^{\text {th }}$ to 18 th $^{\text {th }}$ century under the rubrics of mostly indigenous settlement, morphed into British colonial and Geddes Dhaka during the 19th $20^{\text {th }}$ century, culminating into the emergence of JSB Complex Dhaka in a neocolonial Capitalist driven world order in the early sixties during cold war era. The 3 layers of city segment can be seen as an outcome of the changing political setting from local to European (British) colonial and finally under US governed global political order. This paper will try to connect the 3 stages of spatial transformation with the element of shifting power and resource control in line with the theoretical framework by Kim Dovey which states that space creation in a city is articulated and constructed by the power structure through the control of resources and economic influence.
\end{abstract}

Key Words- Jatio Sangsad Bhaban, Dhaka, Urban Planning, Louis I kahn.

\section{Introduction}

Dhaka, the capital of Bangladesh, ${ }^{1}$ has been one of the major cities of the subcontinent since the Mughal period in the $16^{\text {th }}$ century. Once a Venice of the east it experienced a series of morphological and social change over the last 400 years, emerging in the $20^{\text {th }}$ century as a capital city of independent Bangladesh. Dhaka's fortunes during this period have been mixed. During British rule in 1715 the capital was shifted from Dhaka and again the city was stripped of its capital status after the annulment of partition in 1911. Dhaka re-emerged as a significant city when it

\footnotetext{
${ }^{1}$ Bangladesh emerged as an independent country in 1971 after a bloody war with Pakistan. It was regarded as East Pakistan prior to its independence.
}

became the capital city of East Pakistan after Pakistan became independent Finally it was established as a major metropolis after the independence of Bangladesh [1].

Morphologically Dhaka has three distinct phases. First, tpre-colonial Dhaka, which grew along the river Buriganga during the $14^{\text {th }}$ century, evolving as a commercial centre composed of mainly traders, artisans and craftsmen [2]. The city wass comprised of distinct physical entities: Mahallas or neighbourhoods and Chowk, a melting pot and hub for all cultural, social, political and business activities located at the intersection of two or more streets.

Second, colonial Dhaka which itself had two distinct phases: the transitional phase and the phase of consolidation [3]. In the transitional phase, due to British manipulation of resources, especially after the decline of Dhaka's traditional cotton industry with the introduction of cheaper cotton from Manchester, Dhaka became an almost deserted city, characterised by deurbanization : 'In about forty years the city's housing stock had fallen from 44,000 houses in 1801 to 10830 in 1838 but increased somewhat to 16,279 in 1830' [4]. After the shifting of colonial resource control from the East India company to the British Crown, the urban activities of Dhaka improved[5]. The establishment of the Dhaka Municipality under the Bengal Act 3 expedited urbanisation due to systematic control of revenue and resources[6]. After a brief stagnant period at the end of the $19^{\text {th }}$ century Dhaka's urban growth reached a new height - the consolidation phase,- when Dhaka was elevated to the rank of provincial capital of Bengal in 1905. However, in 1911, this decision was reversed due to lack of control of power and resources by local muslims and Dhaka lost its pomp and glory and was reduced to an ordinary city [7].

For a brief period after the independence of Pakistan from British Colonial rule Dhaka regained its importance as the capital city of East Pakistan. After the establishment of the Dhaka Improvement Trust (DIK) in 1954, Dhaka experienced further rejuvenation in its urban activities. This is the 
beginning of the third phase of Dhaka's development. In 1959 the Minoprio, McFarlane masterplan was devised under the aegis of DIT [8]. In 1962, Pakistani president Ayub Khan envisioned the commissioning of a national assembly complex, Jatio Sangsad Bhaban (JSB), in Dhaka, a landmark decision that was a significant influence on the morphological mosaic of Dhaka. The commissioning of the American architect Louis I Kahn in the early 1960s, during the cold war era, can be regarded as an indirect American neo-colonial influence on the urban fabric of Dhaka [9]. The involvement of America in the commissioning of JSB can be placed in the context of America's global attempts at economic control under the guise of transferring US aid. America's aim at this time was to increase its reach in strategically important developing nations, using the cultural weapons of art and architecture. Pakistan was one of the major recipients of military, technological and cultural assistance from the US [10]. The planning of JSB by Kahn can be perceived as cultural influence through the control of resources ,significantly shaping the urban development of Dhaka.

Through these three phases outlined above, Dhaka emerged as a hybrid city as a result of successive changes in power and textual character. The exercise of power is evident mainly through resource control manifested physically in the changing pattern of urban form. The construction of city space is mostly negotiated through economic and monetary dominance and subordinace of power structure. Tonkis argues in this regard, "the politics of urban space is also played out through economic and symbolic claims to the city" [11]. This article also considers a Marxist perspective when examining the planning of JSB, questioning the American capitalist mode of modern planning. Klosterman argues, 'Marxists interpret planner's actions in each sphere as primarily serving the interests of capital at the expanse of society' [12]. Susser's evaluation the changing urban pattern is also pertinent here, 'Spatial transformation must be understood in the broader context of social transformation: space does not reflect society, it expresses it, it is a fundamental dimension of society [power struggle and control over capital and resources etc], inseparable from the overall process of social organisation and social change' [13]. The changing pattern of urban spaces in Dhaka will be examined in line with the wider context of shifting social and authoritarian change, mainly viewed through the lens of Dovey's theory, which states,, "The Nexus of Built form with power is, at one level, a tautological truth place creation is determined by those in control of resources" [14].

\section{Socio-Political Construction of Space}

Tonkiss contends that the socio-political milieu, in particular the economics of urban society, is linked to complex urban forms [15]. Castell [16]and Giddens [17](visualise urban built forms as representing socio-political control, economic history and the cultural essence of the people. Bounds argues in this regard, 'The city is part of the wider society, with socio-political processes amenable to urban analysis. It is an area in which the structure and process of society [including economic issues] can be studied' [18]. According to many scholars the spatial aspect of the city is a mirror of the values, customs, politics, resource control and way of life of city people[19]. The city constitutes not only the 'setting' but the 'stakes' of political and economic contestation [20]. Urban space emerges as a discourse of power struggle (hinging mainly on resource control), as can be understood from Dovey's statement, 'A large scale built or urban form, in mass or volume, inherently signifies the power necessary for its production. The juxtaposition of large and small inherently signifies a relation of power and may be linked to discourses of domination [economic etc] and intimidation' [21]. Thus the physical dimension of the city can be represented as a complex social, financial and authoritarian milieu of society.

Urban planning as a discourse is inherently a tool of imposing the intention of higher order. Findley [22].suggests the discipline of architecture and planning is a vehicle of transmitting the caprice and whim of resource control by authority. Moreover, Findley states colonialism cast deep shadows by means of urban planning. Similarly, Njoh [23] writes that the mode of introduction of urban planning and policy by the British was to inculcate the idea of civilising the "inferior race" or a "Mission Civilisatrice" in the guise of control. Yiftachel argues, "Ground breaking work [planning work] based mainly on structural analysis of U.S and British cities, shows how the modern capitalist state in general, and urban planning in particular, facilitate capital accumulation and therefore reproduce class inequalities' [24]. Jatio Sangsad Bhaban, as a product of an American architect in Bangladesh, represents a US version of the city, perhaps promoting capital accumulation and discrimination.

\section{City, Urban Space and Resource}

The city is a major stage in the struggle of control over resource. The claim on urban space is guided, motivated and influenced by the authority over resource [25]. The struggle over space as a means to control resources is a historical fact. City space is a testament of time, a visual and textual historic record of all exploitation, extraction, subversion, 
domination, subtraction, promotion, accentuation, concoction, articulation, action and inaction. 'Cities might capture and concentrate wider struggles over exploitation and inequality, but they also posed specific questions of justice on the ownership and distribution of public space collective goods' [26]. The economic dimension of urban planning has also been illustrated in the writing of Yiftachel, who argues four different aspect of planning: territorial, procedural, socio-economic and cultural dimension [27]. This article will mainly address the economic dimension of planning hinging of Kim Dovey's theory.

The article focuses on three successive phases of urban development in Dhaka in line with Kim Dovey's theory on control of resources as a vehicle of space formation. Sen's views on the growth of the social structure of Dhaka as a response to economic control imparting astrong influence on the social construction of space supports our hypothesis, "Thus in terms of political economy, or in other words, sociologically, the society and social structure of the capital Dhaka has been shaped under two major modes of production, namely feudalism and capitalism” [28].

\section{The Southern Segment: Old Dhaka as a Spatial Product of Indigenous Politics and Control of Resources}

The history of pre-Mughal Dhaka is obscure. Old Dhaka came into importance when Dhaka became the capital city of the Mughal empire in the $17^{\text {th }}$ century [29]. Its importance as capital city mainly revolved around its economic and business potential. Sen asserts, 'its importance lay not only in being the capital of the Bengal province, but also in monopolizing its trade and commerce' [30]. Thus its economic activities and issues related to resource is a determinant shaping its socio-political structure as well as its physical formation.

In the late $17^{\text {th }}$ century after the mass trade invasion of Dhaka by the English,the Dutch,the French, the Portugese, the Greeks and the Armenians, Dhaka's commerce and trade reached its peak. Dhaka muslin was famous and lured large numbers of European traders [31]. Dhaka in the $17^{\text {th }}$ century dominated by participants in the textile industry, such as weavers, spinners, bleachers, washermen, cleaners, and other workers included masons, carpenters, thatchers, boatmen, palki bearers, animal minders, grass cutters, slaves, factory owners, banians, gomosthas, paikers, dalals, kayals, sarrafs, mahajans, potdars, artisans, boat manufacturers, and shopkeepers. All these made Dhaka a vibrant business centre. 'Besides the commercial class which comprised of groups of tradesmen and ruling class of Mughal nobility there was an artisan class engaged in localized small scale industries that met the needs of the city' [32].The $18^{\text {th }}$ century experienced huge growth in trading and manufacturing.

The thriving business activities in old Dhaka were a significant influence on the physical dimensions of the old city. Almost every street was comprised of bazaars or markets and chawks or business meeting place [33]( (Mowla, 2003; Sen 2011). Mahallas (neighbourhoods) emerged in response to clustering of guilds and merchants. Thus the physical character of old Dhaka was mainly guided by the commercial attributes of the society. "The names of different localities e.g Shkharibazar, Tantibazar, Jugainagar, Sutrapur, Kumartoli and Goalnagar etc. show that persons following the same occupation used to live in compact groups' [34]. Mahallas or neighbourhoods were spotted with large numbers of shopfronts representing commerce and business as the core of spatial domain. 'Series of shops fronting onto the main street of Mahalla, and inter connected mahallas give rise to a pattern unique to Dhaka [35].

The business centres and neighbourhoods of precolonial Dhaka were divided into 22 mahallas (sectors) headed by panchayat (a civic body) comprised of 22 sardars (leaders) or mir-e-mahalla or neighbourhood leader, assisted by a deputy naibsardar [36]. The sardars, who were responsible for command and control of old Dhaka, were mainly wealthy traders, merchants and businessman [37]. 'The heads of the Panchayats and Mahalla are generally elected and invariably wealthy persons.' [38]. Mowla argues in connection to the role of panchayat, 'The panchayet, as an institution played an important role in bringing about changes, including spatial developments, responding to the changing needs, but within a traditional social framework' [39].Thus the traditional power structure was dominated by the affluent class 'Panchayat' who set rules and norms for society, including in relation to the physical space to shape the city. Their control over resources by panchayat members as rich merchants is assumed to be the prime defining factor in shaping the physical dimension of old Dhaka [40].

05 The Transitional Middle Segment: The Imposition of British Colonial Power and Control of Resource

The underlying purpose of British colonial rule was entirely economic exploitation. Njoh argues, 'In this regard British colonial enterprise is said to have been motivated by economic reasons, while the French were driven in colonialism by a desire to bolster their countries prestige at home, throughout Europe and globally' [41]. Dhaka was no exception from this inherent idea of British colonial economic 
exploitation. During British rule, 'Indeed bazaar (market) was in a sense an epicenter in the struggle for colonial rule' [42]. The creation of Dhaka's urban space was absolutely dominated by British control of trade, commerce and industry. Space emerged as a foreground for all economic activities, a symbolic mirror of economic peak and fall. Sen argues in relation to European settlement in India including Bengal 'European settlements and their patterns were primarily dependent on the changing nature of the international political economy and internal political climate" [43]. Habib and Meulder state, 'By establishing power (military and administrative centre) at the centre of town ,British made it one of its central task to take the control and regulate the market place - the prominent public place of Bengal' [44].

There are three distinct parts to British colonial rule in Dhaka: the early British phase (1763-1905), the phase of provincial capital (1905-1912) and the final British phase (1912-1947) [45] . The changing pattern of the physical setting of Dhaka during colonial rule is directly connected to the economic highs and lows of Dhaka in all three phases. The three phases demonstrate different physical settings due to economic upheaval because of British manipulation and control of resources.

During the early $18^{\text {th }}$ century Dhaka was in decline due to the shifting of the capital to Murshidabad. In late $18^{\text {th }}$ century, as cotton production declined Dhaka lost its status as a commercial city. Several factors contributed to this decline, including the industrial revolution in England, the imposition of heavy duties on Indian import items by the British, and less demand for Indian textiles [46]. The systematic annihilation of the Indian and Bengal cotton industry by the British is evident from Yafa's groundbreaking treatise 'cotton' [47] and in Armstrong's description of American manipulation of Japanese cotton, an appropriate parallel to the situation of Bengal cotton [48]. Islam and Adnan argue, "Most of the cottage industries promoting muslin were closed down as they were adversely affected by the policies of the British colonial rulers regarding a promotion of machine made cotton. Exports of muslin were severely affected by the taxation policies of government. The weavers moved to rural areas to earn their livelihood from agriculture. Both the population and area of Dhaka shrunk during the period 1800-1840' [49].

This British control of trade and commerce had a serious impact on the urbanization process of Dhaka. Rapid deurbanisation took place in the early $19^{\text {th }}$ century due to the economic manipulation of British. Localities like Narinda, Warli and Fulbaria, which were densely populated became almost deserted.
Other areas like Fulbaria, Dewan Bazaar and Monohar Bazaar in the north also became deurbanised [50]. Tailor states, "the decline of manufacturing and commerce, as may be naturally expected, has occasioned a diminution of the population of the city. In 1800 the inhabitants were 200,000 but now [1840] they do not amount to more than 63,038 in number, according to the census of 1838 poverty has increased in a far greater ratio than population decreased." [51]. Lord Clive in 1757 compared Dhaka with the city of London in terms of opulence and population [52], while Trevelyan visualized Dhaka before the Select Committee of the House of Lords in 1853 that, "the jungle and malaria are fast encroaching ... Dacca the Manchester of India has fallen from a very flourishing town to a very poor and small town [53].

After the British Government took control of Bengal and Dhaka in 1857 from the East India Company, much significant economic revival and development started to take place in Dhaka, in the period known as the period consolidation. A financial institution Dhaka Bank was established in 1864 under the patronage of European indigo planters, merchants and landlords [54]. 'The presence of this bank in Dhaka transformed the city into the financial centre of east Bengal' [55]. Developments like the Dhaka district board, the foundation of a government school and college in Dhaka contributed to the emergence of 'civil society' and also contributed significantly to the development of Dhaka. By 1866, District Courts, Magistrate Courts, and other civil offices were established in Dhaka [56]. 'The construction of this new development was called civil line or the European quarter of Dhaka. New official and courts triggered the whole series of this development and completed a fundamental change in the urban fabric' [57].

With the establishment of the Dhaka Municipal corporation n new era was ushered in. 'The Bengal Act III of1864 which led to the establishment of the Dhaka Municipality was a land mark in the city's urban development [58]. British government policy on trade, commerce and revenue collection as a result of the formation of the municipality contributed significantly to the physical development of Dhaka [59]. 'As soon as the commissioner had secured the necessary tax revenue in 1864, the Corporation set about organizing both the development and conservancy of the city, putting much emphasis upon sanitary improvement. Very soon the two main streets, Nawabpur and Bazaar Streets, had been remetalled, many mud roads and lanes repaired, and some metalled, a few of the narrower streets widened [60].Thus the consolidation of urban Dhaka under the 
governance of the Dhaka Municipal Corporation began [61].

At about the same the railway colony and the cantonment (Peel Khana and Purana Paltan) also emerged as an urban precinct, enriching the mosaic of Dhaka [62]. The inception of the railway track was a landmark event in 1885 . The centre was shifted then from the old indigenous core to the new functional zoning space .The railway line practically demarcated the indigenous and new European developments [63]. The early 20th century also saw the rise of urban activities in Dhaka after the British declared Dhaka as the provincial capital of Bengal in 1905. Later, after the annulment of the decision in 1911, on 2 February 1912, the British government decided to establish the University of Dhaka, which had a huge impact on the urban mosaic of the middle Dhaka $^{2}$ [64]. Dhaka University is located on a large parcel of land in the centre of urban Dhaka. The Dhaka University campus was developed in line with modern European university cities [65].

\section{Modern Dhaka: The North \\ Jatio Sangsad Complex: The Emergence of Neocolonial Planning as a Resource Control of Capitalist America}

After a brief period of stagnation in urban growth after the establishment of Dhaka University and the development of the Ramna area, around the railway precinct, the growth of Dhaka began to increase after the partition of India in 1947. After 1947 Dhaka emerged as the capital city of East Pakistan. Choudhury argues, 'the sudden flow of people to Dhaka in the post-1947 period created the 'new Dhaka' in the highland available north, north-east and north-west of Ramna [centre of colonial Dhaka]" [66]. During this period, under the aegis of the dictatorial power of West Pakistani bureaucrats several planning instruments and laws were formulated for the city of Dhaka. ${ }^{3}$ In 1952 the Building Construction Act of 1952 was formulated. In 1953 the Town Improvement Act of 1953 for metropolitan Dhaka was envisioned and the regulatory body 'Dhaka Improvement Trust' came

\footnotetext{
${ }^{2}$ The British decided to establish Dhaka University to appease the people of Dhaka (Choudhury et al., 2012)

${ }^{3}$ When Pakistan emerged independent from British india it was divided into distinct parts, East and West Pakistan. Apart from religion the two parts had no common ties. They differed in terms of culture, race,ethnicity,lifestyle and all other aspects of life. Despite a considerable contribution to the overall economy of Pakistan, East Pakistan was neglected and subjugated by the west. In 1971 East Pakistan became an independent nation Bangladesh and Dhaka became the capital city.
}

into being [67].The Dhaka master plan $1959^{4}$ formulated by a British firm Minoprio, Spencely and MacFarlane was prepared under the guidance of the Dhaka Improvement Trust. The underlying idea of the plan is to manage the rapid growth of Dhaka in line with the increase in population [68]( (Begum, 2007). Dhaka was 220 square miles at that time, with a population of 57,5000 [69].This plan did not materialise because, according to Hayder 'Thus the future of the city eventually fell into the hands of tyrannical and whimsical decision makers' [70]. Most of these bureaucrats were foreign trained and influenced by the British Civil Service.

Despite Pakistan having emerged independent after breaking the shackles of British colonialism, it fell into the grip of another colonial superpower. Young argues, 'although the formerly colonized territories gradually had their political sovereignty returned to them, they nevertheless remained subject to the effective control of the major world powers' [71]. When Pakistan received its independence, global politics was reshaping in the name of the cold war. British colonial countries gradually started to polarise either for the US or the USSR. Washington policy makers perceived Pakistan as astrategically important country [72].

In mid-1949 White House staff assistant Stephen J. Spingran argued for the strategic importance of Pakistan in a series of papers and memoranda. The case for closer relations with Pakistan, he emphasized, rested almost exclusively on strategic grounds. Pakistan's proximity to the Soviet Union; its proximity to the oil fields of the Middle East; its potential role in the defense of both the Indian ocean area and Indian subcontinent; its position as the largest Muslim nation in the world; and its army, which he called the best in the middle east' [73].

Thus, after independence Pakistan's development was supported by America, but at a cost. Pakistan was once again subjugated to a colonial power, this time the US with its capitalist vision and consumer lifestyle. Pakistan received US\$1.2 to US\$1.5 billion between 1954 and 1965 [74]. Economic assistance in the form of technical, cultural and agricultural grants amounted to almost US\$3 billion. Lerski argues,

One wonders whether Pakistan's first two five years plans would ever have become such striking success without American financed aid and technical assistance. Indeed, the United States can take much of the credit for

\footnotetext{
${ }^{4}$ The firm was instructed to formulate a plan on 26 August 1957 by the Secretary for Commonwealth Relations for the Dhaka Improvement Trust under the Technical Co-Operation scheme of the Colombo Plan. It tookone year to prepare the working plan.
} 
Pakistan's having become, under the benevolent dictatorship of president Ayub, an Asian showpiece of economic development and political stability[75].

The inherent idea of the US aid policy is to control resources and propagate American values and lifestyle in developing countries [76]. The Clay Committee (1962), prior to the commissioning of Jatio Sangsad Bhaban argued that the US “... should not extend aid which is inconsistent with our beliefs, democratic traditions and knowledge of economic organization and consequence” [77].

Against such a setting, in 1962, the president of Pakistan envisioned the commissioning of the JSB in Dhaka. Although the JSB was not commissioned as a response to direct US aid, it was an indirect result of the US Information and Cultural Exchange Act 1948, known as the Smith Mundit Law [78]. ${ }^{5}$ This law was formulated to influence cultural artefacts in developing countries through media propaganda, exhibitions, publications and cultural exchange programs [79]. Architecture and urban planning, like any other product, was mostly regarded as a consumerist symbol transferred to different cultures as a means to propagate the values and lifestyle of the American capitalist idea [80]. Kasizek questions "Clearly, in the case of the complex at Dhaka [JSB], this dynamic indicates a colonial mentality, in which the ideals of a greater power are transposed onto one unlikely to resist. Does this make Sher-e-bangla Nagar an example of American Cultural Imperialism” [81].

The site for Jatio Sangsad Bhaban was selected on the northern outskirts of Dhaka. By this time Dhaka had expanded from six square miles in 1947 to 25 square miles in 1962 [82]. The site was selected on farm land. The altitude of the site and its quite and serene setting were regarded as important factors in the selection of the site. Its location between two major thoroughfares, Maymenshing Road on the East and Mirpur Road on the west, was a defining factor in the selection of the site. The existing low land was regarded as appropriate for of the creation of a lake and this also contributed to the suitability of the site. A possibility of future expansion towards the north was also critical in the selection of the site. [83]( (file no. -w- cap-58/ace collection no -10, year -1968).

With the commissioning of JSB, a neo-colonial order of planning started to shape Dhaka, revolving around the JSB complex. The gigantic physical imprint of the JSB immensely influenced urban planning in

\footnotetext{
${ }^{5}$ Under this law local elites were encouraged to take up higher studies in the US. Muzharul Islam, who was educated in the US, was instrumental in the commissioning of American Architect Louis I. Kahn for the JSB (Choudhury and Armstrong, 2013).
}

Dhaka. In scale the project dominated the landscape, a built metaphor for the dominance of the neocolonialist US. The policy makers related to land use inspired by American cultural propaganda during the cold war period and the physical attributes of the JSB started to generate out of scale land projects for affluent members of society, disregarding the fact that many people in Dhaka were struggling to have even the basic necessities at this time.The western value laden bureaucrats of the DIT developed housing projects like Gulshan Model Town (1961), Banani (1964), Uttara (1965) and Baridhara (1962) following the western model of garden houses [84], perhaps inspired by the about to commence mega scale of the JSB.

After the independence of Bangladesh in 1971 the scenario remained same for land policy and land allocation in Dhaka. American capitalist policy, especially after 1975, along with the visible presence of JSB shaped the psyche of new Bangladeshi bureaucrats in all aspects of life, including land allocation policy [85]. ${ }^{6}$ Sen wrote,

'The economic gap that existed between a small section of rich and a vast poorer section of the population in the first phase of Bangladesh period widened further after august 1975, when the Post Mujib government introduced a kind of capitalist economy reversing the socialist path of economic development pursued by the first government. In this situation a compador capitalist class which had appeared in the social structure of post liberation Bangladesh begin to control the socio-political life of the country. Because of the pursuit of the capitalist path of economic development, the land of Dhaka city came to be distributed unevenly. According to a study undertaken by Kamal Siddique and his colleagues,only $30 \%$ people of the city controlled $80 \%$ of land .In the name of 'housing societies' the affluent families were getting exemption of the ceiling of city land ownership and grabbing city land by sheer might of money. The city land has been used mostly for residential purposes, about $88 \%$.the said study which conducted in 1986 reveals the fact that $2 \%$ population of Dhaka city belong to upper class Owned $15 \%$ land, $28 \%$ population belonging to upper middle class owned $20 \%$, and $40 \%$ population belonging to poor class owned nothing. There was, in other words, a growing trend of concentration of land ownership in Dhaka City [86]. All these disproportionate distribution of land allocation reflect

\footnotetext{
6 After a change of government in 1975, the new wave of American influence began. During this period Bangladesh's various bilateral cultural and academic programs were heavily funded by USAID. Apart from the physical presence of JSB American influence was evident through cinema, mass-media and other forms of communication (Choudhury and Armstrong, 2012 ).
} 
American way of capitalist thought, which the clay committee envisioned in 1962 prior to commissioning of American Architect Louis I Kahn for Jatio Sangsad Bhaban.

\section{In Retrospect}

The paper discusses three phases of Dhaka: precolonial, British colonial and American neo-colonial in line with Kim Dovey's statement "Place creation is determined by those in control of resources" [87]. An attempt has been made to unravel the underlying dynamics of urban space in Dhaka in relation to resource control by understanding the power structure of each individual phase, which culminated in the commission of the JSB in Dhaka, under the rubrics of American influence of control of resource. The central aim of the paper is the examination of neo-colonial planning, which can be seen at its climax in the JSB. Dhaka's three urban phases share a common thread of shifting power and resource control. The pre-colonial urban phase of Dhaka was governed by panchayat, a group of wealthy people who had absolute authority on trade and commerce. The early 19th century colonial period was marked by deurbanisation due to the decline of local resources under the British, while the late 19th century's urban growth during the colonial period reached momentum due to regulated control of resources through the Dhaka Municipality Corporation and other financial institutions. Early $20^{\text {th }}$ century Dhaka was marked by the establishment of the University as a result of complex dynamics on control of resources in Dhaka between Hindu and Muslims. Finally the JSB emerged as under the neocolonial world order of American capitalist economy and consumerism in the cold war era.

The political and economic setting over each phase impacted the urban fabric of the city. The precolonial setting is marked by narrow streets with low key down to earth physical structures. The colonial setting is a derivative of British planning and structures in a greater scale and finally the neocolonial setting, represented by JSB, is on an even larger global scale mirroring American global power, dwarfing all that went before.The changing political and economic scenarios thus have a distinct influence on the changing land pattern and urban fabric of Dhaka.

The JSB has been a significant influence in Dhaka's urban fabric. The disproportionate distribution of land for this gigantic project reflects American capitalist and consumerist life style and made a permanent impression on the scarce land allocation of the city. Hubert argues that this neo-colonial order has been instrumental in setting the American standard for Dhaka [88]( (1984). The JSB is not only a symbol of neo-colonialism but can also be considered a symbol of inequity in matters of social justice and wealth distribution. . Ghafur argues, "However, issues of poverty, gender, social justice and environmental sustainability are some of the crucial concepts of contemporary development relevance and not considered by Kahn in Sher-EBangla Nagar' [89]. The time is ripe to question the existence of the JSB in line with the economic realities of ultra poor Dhaka. 'Marxist arguments can't be evaluated in the abstract but must be examined critically in the light of present economic and political realities' [90]( (Klosterman, 1985, p. 95). JSB's modernist approach in urban planning can be represented as a physical translation of American capitalism The marginalisation of the working class [91] is reflected through the gargantuan physical presence of JSB, which marginalises the landless population of Dhaka from the centre to the periphery. Thus the land use of Dhaka can be perceived as an outcome of the constant interplay of foreign values and exploitation

\section{References :}

[1] Choudhury Bayezid, P. A., Paul Jones, Why Geddes Plan Did Not Materialise: Planning for Planning for Planning for Planning Sake in the Case of Dhaka.'. 5th International Urban Design Conference, Melbourne, 2012.

[2] Mowla, Q. A. Urbanization and The Morphology of Dhaka-a Historic Perspective." Journal of Asiatic Society 48(1): 145-170, (2003)"

[3] Mowla, Q. A. "Urbanization and The Morphology of Dhaka-a Historic Perspective." Journal of Asiatic Society 48(1): 145-170, 2003.

[4]p161, Mowla, Q. A,"Urbanization and The Morphology of Dhaka-a Historic Perspective." Journal of Asiatic Society 48(1): 145-170,2003.

[5] Mowla, Q. A, "Urbanization and The Morphology of Dhaka-a Historic Perspective." Journal of Asiatic Society 48(1): 145$170,2003$.

Sen, R. Society and Social Structure in Capital Dhaka Since The Mughal Period. 400 years of Capital Dhaka and Beyond. A. M. Choudhury. Dhaka, Asiatic Society. 1,2011.

[6] Ahmed, S. U. Dhaka: A Study in Urban History and Development 1840-1921. Dhaka, Academia Press an Publishers Library,2010.

[7] Choudhury Bayezid, P. A., Paul Jones, Why Geddes Plan Did Not Materialise: Planning for Planning for Planning for Planning Sake in the Case of Dhaka.'. 5th International Urban Design Conference, Melbourne,2012.

[8] Zaman, Q.M.mahtab-Uz-, S. S. Y. L,City Expansion Policy versus Compact City Demand: The Case of Dhaka. Compact Cities. R. Mike Jenks. London and New York,2000.

[9] Choudhury Bayezid, P. A, Jatio Sangsad Bhaban and Notion of American Cultural Imperialism in The Cold War Era. Architectural and Civil Engineering Conference, Singapore,2013.

[10] McMahon, J. R, "United States Cold War strategy in South Asia: Making a military commitment to Pakistan, 1947-1954," The Journal of American History, vol.75(3), pp. 812-840, 1988.

[11]p.5, Tonkiss, F., Space, The City and Social Theory : Social Relations and Urban Forms. Cambridge, Polity,2005. 
[12]p.94-95, Klosterman, R. E, "Arguments for and Against Planning." Town Planning Review 56(1): 5-20,1995.

[13]p.393, Susser, I., Ed., The Castells Reader on Cities Social Theory. Oxford, Blackwell Publishers Inc, 2002.

[14] p.1, Dovey, K, Framing places : Mediating Power in Built Form. London ; New York, Routledge, 1999.

[15] Tonkiss, F, Space, The City and Social Theory : Social Relations and Urban Forms. Cambridge, Polity, 2005.

[16] Castells, M, City, Class and Power. New York, St. Martin's Press, 1978.

[17] Geddins, A, Central Problems in Social Theory. Berkely, University of California Press, 1979.

[18]p.43, Bounds, M, Urban Social Theory. Oxford, New York, Oxford University Press, 2004.

[19] Low, M, Cities as Space of Democracy. Spaces of Democracy. C. B. M. Low. London,Thousand Oaks, New Delhi, Sage Publications, 2004. Castells, M. City, Class and Power. New York, St. Martin's Press, 1978. Amin, A. N. T. Cities: Reimagining the Urban. Cambridge, Polity Press, 2002.

[20] Lefebvre, H, The Production of Space. Oxford, OX, UK ; Cambridge, Mass., USA, Blackwell, 1991.

[21]p.18, Dovey, K, Framing places : Mediating Power in Built Form. London ; New York, Routledge, 1999.

[22] Findley, L, Architecture, Politics and Cultural Agency. New York, Routledge, 2005.

[23] Njoh, A. J ,Planning power: Town Planning and Social Control in Colonial Africa. London ; New York, UCL Press, (2007).

[24] p.397, Yiftachel, O, "Planning and Social Control : Exploring the Dark Side." Journal of Planning Literature 12(395). Retrieved from http://jpl.sagepub.com/content/12/4/395, 1998

[25] Cuthbert, A. R. Understanding cities : method in urban design. Milton Park, Abingdon, Oxon ; New York, Routledge, 2005.

[26]pp. 61-62, Tonkiss, F,' Space, The City and Social Theory : Social Relations and Urban Forms. Cambridge, Polity. 2005.

[27] Yiftachel, O,"Planning and Social Control : Exploring the Dark Side." Journal of Planning Literature 12(395). Retrieved from http://jpl.sagepub.com/content/12/4/395, 1998.

[28]p.101, Sen, R, Society and Social Structure in Capital Dhaka Since The Mughal Period. 400 years of Capital Dhaka and Beyond. A. M. Choudhury. Dhaka, Asiatic Society. 1, 2011.

[29] Chowdhury A,Faruqui, . S, Physical Growth of Dhaka City. Dhaka: Past, Present and Future. S. Ahmed. Dhaka, Asiatic Society, 2009.

[30] p.107, Sen, R, Society and Social Structure in Capital Dhaka Since The Mughal Period. 400 years of Capital Dhaka and Beyond. A. M. Choudhury. Dhaka, Asiatic Society. 1, 2011.

[31] Choudhury, A. M. Dhaka Under The Mughal Subahdars, 1608-1704. 400 years of Capital Dhaka and Beyond. A. M. C. e. el. Dhaka, Asiatic Society of Bengal. 1, 2011.

[32] p.108, Sen, R, Society and Social Structure in Capital Dhaka Since The Mughal Period. 400 years of Capital Dhaka and Beyond. A. M. Choudhury. Dhaka, Asiatic Society. 1, 2011.

[33] Mowla, Q. A, "Urbanization and The Morphology of Dhaka-a Historic Perspective." Journal of Asiatic Society 48(1): 145-170, 2003. Sen, R. Society and Social Structure in Capital Dhaka Since The Mughal Period. 400 years of Capital Dhaka and Beyond. A. M. Choudhury. Dhaka, Asiatic Society. 1, 2011.

[34]p.111, Sen, R, Society and Social Structure in Capital Dhaka Since The Mughal Period. 400 years of Capital Dhaka and Beyond. A. M. Choudhury. Dhaka, Asiatic Society. 1,2011.

[35]p.267, Mowla, Q. A. "Settlement Texture : Study of Mahalla in Dhaka." Journal of Urban Design 2(3), 1997.

[36] Mowla, Q. A. "Settlement Texture : Study of Mahalla in Dhaka." Journal of Urban Design 2(3), Sen, R. (2011). Society and Social Structure in Capital Dhaka Since The Mughal Period. 400 years of Capital Dhaka and Beyond. A. M. Choudhury. Dhaka, Asiatic Society. 1, 1997..
[37] Sen, R, Society and Social Structure in Capital Dhaka Since The Mughal Period. 400 years of Capital Dhaka and Beyond. A. M. Choudhury. Dhaka, Asiatic Society. 1, 2011.

[38]p.116, Sen, R. Society and Social Structure in Capital Dhaka Since The Mughal Period. 400 years of Capital Dhaka and Beyond. A. M. Choudhury. Dhaka, Asiatic Society. 1, 2011..

[39]p.262, Mowla, Q. A, "Settlement Texture : Study of Mahalla in Dhaka." Journal of Urban Design 2(3), 1997.

[40] Mowla, Q. A, "Settlement Texture : Study of Mahalla in Dhaka." Journal of Urban Design 2(3), 1997, Sen, R, Society and Social Structure in Capital Dhaka Since The Mughal Period. 400 years of Capital Dhaka and Beyond. A. M. Choudhury. Dhaka, Asiatic Society. 1,2011.

[41]p.111, Njoh, A. J, Planning power: Town Planning and Social Control in Colonial Africa. London ; New York, UCL Press, 2007. [42] p.265, Meulder, K. H. D. I. A. B, Representation and Public Contestation: The Post Colonial Public Spaces of Dhaka. 400 years of Capital Dhaka and Beyond. A. M. C. e. el. Dhaka, Asiatic Society of Bangladesh. 3,2011.

[43] p.205, Sen, S,"Between Dominance, Departure, Negotiation, and Compromise: European Architecture and Urban Planning Practice in Colonial India." Jpournal of Planning History 9(4),2010.

[44] p.265, Meulder, K. H. D. I. A. B,Representation and Public Contestation: The Post Colonial Public Spaces of Dhaka. 400 years of Capital Dhaka and Beyond. A. M. C. e. el. Dhaka, Asiatic Society of Bangladesh. 3,2011.

[45] Sen, R, Society and Social Structure in Capital Dhaka Since The Mughal Period. 400 years of Capital Dhaka and Beyond. A. M. Choudhury. Dhaka, Asiatic Society. 1.2011.

[46] Islam, M, the Economy of Dhaka. 400 years of Capital dhaka and Beyond. A. M. Choudhury. Dhaka, Asiatic Society of Bangladesh. 2, 2011

[47] Yafa, S, Cotton. New York, Penguin,2005.

[48] Armstrong, P G Architecture in the Mono-no-nai-jidai, Legacies of the Asia-Pacific war: the yakeato generation, London, New York, Routledge imprint of Taylor \& Francis, 1, 216228,2011

[49]p.279, Adnan, I. I. A. S. G,Commercial Land Use in Dhaka : an Analysis of Trends and pattern. 400 years of Capital Dhaka and Beyond. A. M. C. e. el. Dhaka, Asiatic Society of Bangladesh. 3,2011 .

[50] Mowla, Q. A, "Urbanization and The Morphology of Dhaka-a Historic Perspective." Journal of Asiatic Society 48(1): 145$170,2003$.

[51]Taylor in Sen, pp.114-115, Sen, R, Society and Social Structure in Capital Dhaka Since The Mughal Period. 400 years of Capital Dhaka and Beyond. A. M. Choudhury. Dhaka, Asiatic Society. 1.2011.

[52] Mowla, Q. A,"Urbanization and The Morphology of Dhaka-a Historic Perspective." Journal of Asiatic Society 48(1): 145$170,2003$.

[53] Trevalyan in Mowla, p.160, Mowla, Q. A, "Urbanization and The Morphology of Dhaka-a Historic Perspective." Journal of Asiatic Society 48(1): 145-170,2003.

[54] Ahmed, S. U, Dhaka: A Study in Urban History and Development 1840-1921. Dhaka, Academia Press an Publishers Library,2010.

[55] p.115, Ahmed, S. U, Dhaka: A Study in Urban History and Development 1840-1921. Dhaka, Academia Press an Publishers Library,2010.

[56] Meulder, K. H. D. I. A. B,Representation and Public Contestation: The Post Colonial Public Spaces of Dhaka. 400 years of Capital Dhaka and Beyond. A. M. C. e. el. Dhaka, Asiatic Society of Bangladesh. 3,2011.

Sen, R,Society and Social Structure in Capital Dhaka Since The Mughal Period. 400 years of Capital Dhaka and Beyond. A. M. Choudhury. Dhaka, Asiatic Society. 1,2011.. 
[57] p.171, Ahmed, S. U,Dhaka: A Study in Urban History and Development 1840-1921. Dhaka, Academia Press an Publishers Library,2010.

[58] p.171, Ahmed, S. U. (2010). Dhaka: A Study in Urban History and Development 1840-1921. Dhaka, Academia Press an Publishers Library.

[59] Ahmed, S. U,Dhaka: A Study in Urban History and Development 1840-1921. Dhaka, Academia Press an Publishers Library.2010.

[60] p.178, Ahmed, S. U,Dhaka: A Study in Urban History and Development 1840-1921. Dhaka, Academia Press an Publishers Library,2010.

[61] Ahmed, S. U,Dhaka: A Study in Urban History and Development 1840-1921. Dhaka, Academia Press an Publishers Library,2010.

[62] Mowla, Q. A. "Urbanization and The Morphology of Dhaka-a Historic Perspective." Journal of Asiatic Society 48(1): 145170,2003.

[63] p.265, Meulder, K. H. D. I. A. B, Representation and Public Contestation: The Post Colonial Public Spaces of Dhaka. 400 years of Capital Dhaka and Beyond. A. M. C. e. el. Dhaka, Asiatic Society of Bangladesh. 3, 2011.

[64] Choudhury Bayezid, P. A., Paul Jones, Why Geddes Plan Did Not Materialise: Planning for Planning for Planning for Planning Sake in the Case of Dhaka.'. 5th International Urban Design Conference, Melbourne,2012.

[65] Geddes, P, Report On Town Planning, Dacca. Calcutta,1917. Chowdhury A,Faruqui, . S, Physical Growth of Dhaka City. Dhaka: Past, Present and Future. S. Ahmed. Dhaka, Asiatic Society,2009.

[66] p.72, Chowdhury A,Faruqui, . S, Physical Growth of Dhaka City. Dhaka: Past, Present and Future. S. Ahmed. Dhaka, Asiatic Society,2009.

[67] Zaman, Q.M.mahtab-Uz-, S. S. Y. L, City Expansion Policy versus Compact City Demand: The Case of Dhaka. Compact Cities. R. Mike Jenks. London and New York,2000.

[68] Begum, A. "Urban Housing as an Issue of Redistribution through Planning?The Case of Dhaka City." Social Policy and Administration 41(4): 410-418,2007.

[69] Macfarlane, M. a. S. a, Master Plan of Dhaka. Dhaka,1959.

[70] p.98, Hayder, Z,Organic Cities and The Case of Patric Geddes in Dhaka. Architecture. Massachusetts, Massachusetts Institute of Technology. Master of Science, 1987.

[71] p.45, Young, R, Postcolonialism : an historical introduction. Oxford, UK : Blackwell,2001.

[72] Choudhury Bayezid, P. A, Jatio Sangsad Bhaban and Notion of American Cultural Imperialism in The Cold War Era. Architectural and Civil Engineering Conference, Singapore,2013.

[73] McMahon, J. R, "United States Cold War strategy in South Asia: Making a military commitment to Pakistan, 1947-1954," The Journal of American History, vol.75(3), pp. 812-840, 1988.

[74] Lerski, G. J. "The Pakistan-American alliance: A reevaluation of the past decade,” Asian Survey vol. 8(5), pp. 400-415, 1968.

Choudhury Bayezid, P. A, Jatio Sangsad Bhaban and Notion of American Cultural Imperialism in The Cold War Era. Architectural and Civil Engineering Conference, Singapore,2013

[75] p.405, Lerski, G. J. "The Pakistan-American alliance: A reevaluation of the past decade,” Asian Survey vol. 8(5), pp. 400415, 1968.

[76] Choudhury Bayezid, P. A, Jatio Sangsad Bhaban and Notion of American Cultural Imperialism in The Cold War Era. Architectural and Civil Engineering Conference, Singapore,2013.

[77] p.666, Mahajani, U. "Kennedy and the Strategy of Aid,” The Western Political Quarterly, vol. 18(3), pp. 656-668, 1965.

[78] Choudhury Bayezid, P. A, Jatio Sangsad Bhaban and Notion of American Cultural Imperialism in The Cold War Era. Architectural and Civil Engineering Conference, Singapore,2013.

[79] Masey, J. M. and C. M. Morgan, Cold War Confrontations: US Exhibitions and Their Role in the Cultural Cold War,2008.
[80] Chase, J, "The Role of Consumerism in American Architecture." Journal of Architectural Education (1984-) 44(4): 211-224,1991.

Curtis, W. J. R, Modern Architecture Since 1900. London, Phaidon Press Limited, 1996.

[81] Ksiazek, S. W. "Architectural culture in the Fifties: Louis Kahn and the National Assembly Complex in Dhaka," The Journal of the Society of Architectural Historians, vol. 52 (4), pp. 416-435, 1993.

[82] Ghosal, A, Partition of 1947 and The Economy of Dhaka. 400 years of Capital Dhaka and Beyond. A. M. C. e. el. Dhaka, Asiatic Society of Bangladesh. 2,2011.

[83] Government of Bangladesh, File No-W-CAP-58/ACE (1968). D. o. A. E. PWD). Dhaka, Department of Architecture (Erstwhile PWD).

[84] Chowdhury A,Faruqui, . S,Physical Growth of Dhaka City. Dhaka: Past, Present and Future. S. Ahmed. Dhaka, Asiatic Society,2009.

[85] Choudhury, Armstrong , 'Jatio Sangsad Bhaban: A Legacy of British Colonial Urban Development or American Cultural Imperialism?' to be published in Global built Environmental Review

[86]p.127, Sen, S, "Between Dominance, Departure, Negotiation, and Compromise: European Architecture and Urban Planning Practice in Colonial India." Jpournal of Planning History 9(4),2010.

[87] p.1, Dovey, K, Framing places : Mediating Power in Built Form. London ; New York, Routledge,1999.

[88] Hubert, B. J, Kahn's epilogue. Progressive Architecture. 65: $56-67,1984$.

[89]p.221, Ghafur, S, Dhaka After Kahn. ArchitectureOvercoming Constraints, Dhaka, Department of architecture, BUET,2003.

[90] p.95, Klosterman, R. E. "Arguments for and Against Planning." Town Planning Review 56(1): 5-20,1985.

[91] Giddens, A. and W. Hutton, Global capitalism. New York, New Press : Distributed by W.W. Norton,2000

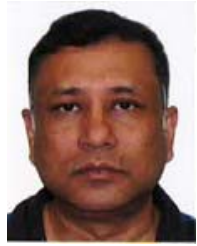

Bayezid Choudhury is a Ph.D Candidate at the University of Sydney. He is a Former Assistant Professor in the Faculty of Architecture and Planning at Bangladesh University of Engineering and Technology

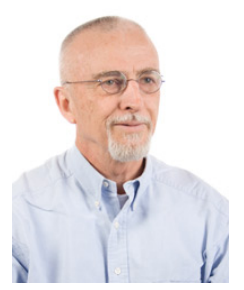

Peter Armstrong is a Senior Lecturer in the Faculty of Architecture and Planning at The University of Sydney. He is an expert in South East Asia and East Asian Architectural History

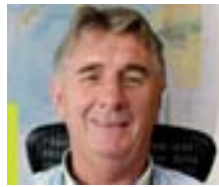

Paul Jones, Associate Professor, Faculty of Architecture and Planning. He is an expert on Third World Urban Planning issues. 


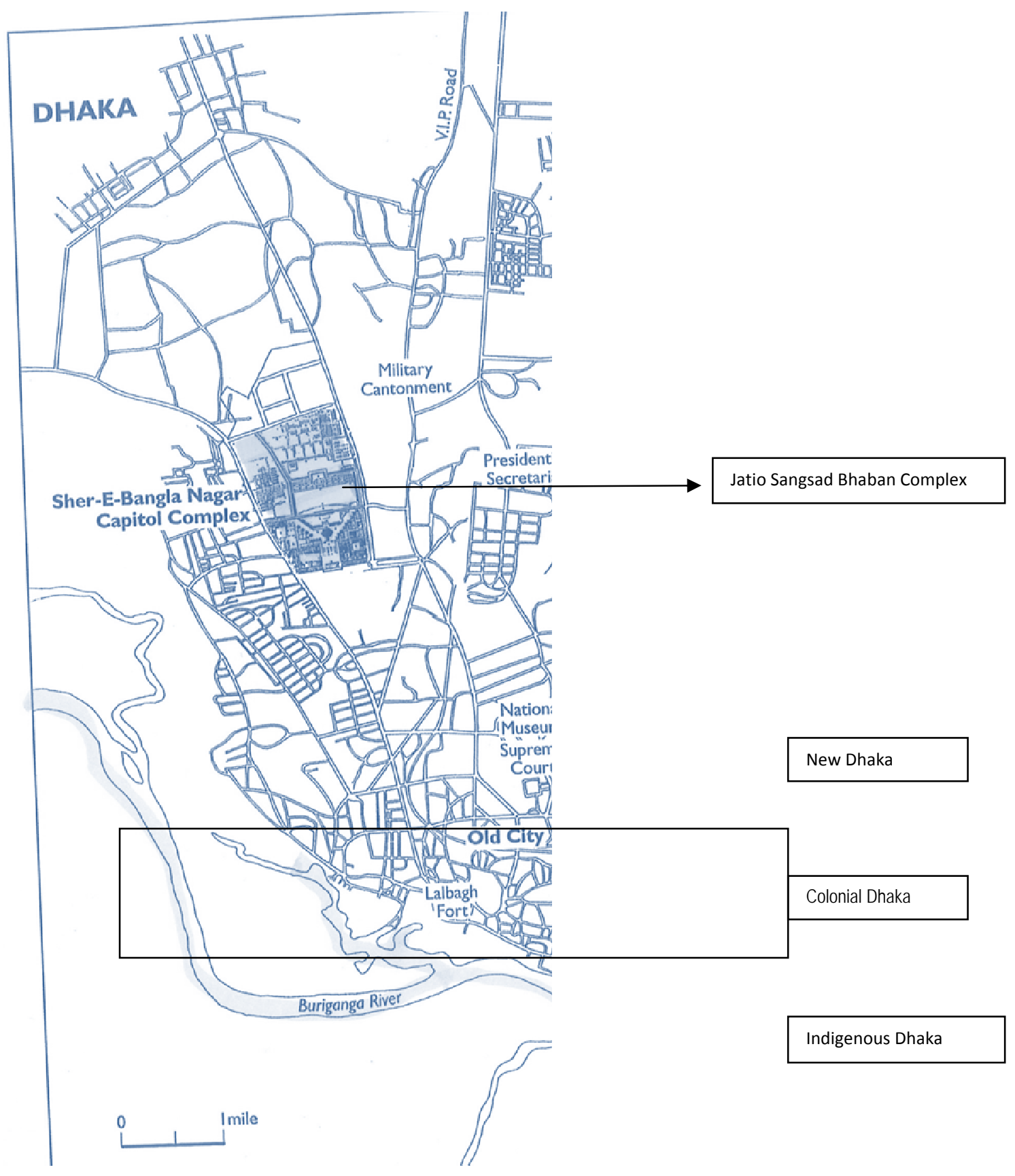

Fig 1 Map of Dhaka City 